\title{
Deficiency of the Caenorhabditis elegans DNA Polymerase $\eta$ Homologue Increases Sensitivity to UV Radiation during Germ-line Development
}

\author{
Tsuyoshi Ohkumo ${ }^{1,2}$, Chikahide Masutani ${ }^{1}$, Toshihiko Eki ${ }^{3}$, and Fumio Hanaoka ${ }^{1,4^{*}}$ \\ ${ }^{1}$ Graduate School of Frontier Biosciences, Osaka University, and SORST, Japan Science and Technology \\ Agency, 1-3 Yamada-oka, Suita, Osaka 565-0871, ${ }^{2}$ Graduate School of Medicine, Osaka University, 2-2 \\ Yamada-oka, Suita, Osaka 565-0871, ${ }^{3}$ Department of Ecological Engineering, Toyohashi University of \\ Technology, Toyohashi, Aichi 441-8580, and ${ }^{4}$ Cellular Physiology Laboratory, RIKEN Discovery Research \\ Institute, Wako-shi, Saitama 351-0198, Japan
}

\begin{abstract}
Defects in the human XPV/POLH gene result in the variant form of the disease xeroderma pigmentosum (XP-V). The gene encodes DNA polymerase $\eta$ (Pol $\eta$ ), which catalyzes translesion synthesis (TLS) past UVinduced cyclobutane pyrimidine dimers (CPDs) and other lesions. To further understand the roles of Pol $\eta$ in multicellular organisms, we analyzed phenotypes caused by suppression of Caenorhabditis elegans POLH (Ce-POLH) by RNA interference (RNAi). F1 and F2 progeny from worms treated by $\mathrm{Ce}$-POLH -specific RNAi grew normally, but F1 eggs laid by worms treated by RNAi against $C e-P O L D$, which encodes Pol $\delta$ did not hatch. These results

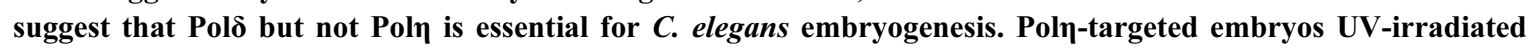
after egg laying were only moderately sensitive. In contrast, Poln-targeted embryos UV-irradiated prior to egg laying exhibited severe sensitivity, indicating that Pol $\eta$ contributes significantly to damage tolerance in $C$. elegans in early embryogenesis but only modestly at later stages. As early embryogenesis is characterized by high levels of DNA replication, Pol $\eta$ may confer UV resistance in $C$. elegans, perhaps by catalyzing TLS in early embryogenesis.
\end{abstract}

Key words: C. elegans/DNA polymerase $\eta /$ RNAi/embryogenesis

\section{Introduction}

DNA can be damaged by a wide range of physical and chemical agents, both endogenous and environmental. To maintain the integrity of the genetic material, cells possess multiple pathways to repair various types of DNA damage (Friedberg et al., 1995a). Nucleotide excision repair (NER) is the main pathway involved in the removal of cyclobutane pyrimidine dimers (CPDs) and (6-4) photoproducts produced by UV radiation, although CPDs are repaired fairly slowly by NER. Unrepaired damage can interfere with basic processes such as DNA replication and transcription and

\footnotetext{
*To whom correspondence should be addressed: Fumio Hanaoka, Graduate School of Frontier Biosciences, Osaka University, 1-3 Yamada-oka, Suita, Osaka 565-0871, Japan.

Tel: +81-6-6879-7975, Fax: +81-6-6877-9382

E-mail: fhanaoka@fbs.osaka-u.ac.jp

Abbreviations: Ce, Caenorhabditis elegans; CPD, cyclobutane pyrimidine dimer; IPTG, isopropyl-1-thio- $\beta$-D-galactoside; NER, nucleotide excision repair; NGM, nematode growth medium; Pol, DNA polymerase; RNAi, RNA interference; TLS, translesion synthesis; XP, xeroderma pigmentosum.
}

lead to mutations and cell death (Friedberg et al., 1995b).

In eukaryotes, another major pathway that circumvents such threats involves DNA polymerases that catalyze translesion synthesis (TLS) past DNA damage. Most TLS polymerases belong to the recently discovered Y-family (Ohmori et al., 2001). After UV irradiation, cultured cells from XP-V patients are defective in DNA replication and exhibit an increased mutation frequency with an altered spectrum (Lehmann et al., 1975; Maher et al., 1976; Wang et al., 1991, 1993; Waters et al., 1993; Stary et al., 2003). The XPV gene encodes human poln (Masutani et al., 1999a; Johnson et al.,1999) which bypasses CPDs by incorporating correct nucleotides (Masutani et al., 1999b, 2000; Johnson et al., 2000; Washington et al., 2001; Kusumoto et al., 2004; McCulloch et al., 2004), indicating that Poln is involved in the relatively accurate TLS pathway for bypass of UV-induced lesions in vivo and in vitro. In contrast, other TLS polymerases, such as Polı (Tisser et al., 2000a, 2000b; Frank et al., 2001), Polк (Gerlach et al., 1999; Ogi et al., 1999; Ohashi et al., 2000a, 2000b), Rev1 (Nelson et al., 1996a; Lin et al., 1999a; Gibbs et al., 2000) and Rev3 with 
Rev7 (Polל) (Lin et al.,1999b; Nelson et al., 1996b; Gibbs et al., 1998), are mutagenic polymerases for bypass of $\mathrm{UV}$-induced lesions.

In XP-V patients, unrepaired UV-induced lesions are more likely to be bypassed by the mutagenic pathway, because the relatively accurate pathway is inactivated. As a result, XP-V patients are sensitive to sunlight and exhibit a concomitant increase in the incidence of cancer. However, the regulation of the TLS polymerases is still unclear (Kannouche and Stary, 2003; Fischhaber and Friedberg, 2005). The nematode $C$. elegans also has TLS polymerases

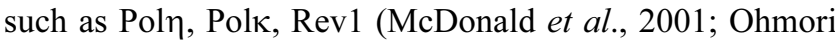
et al., 2001) and Rev3 (Lawrence, 2002), making this model multicellular organism an effective tool to explore DNA repair pathways relevant to TLS in vivo. However, at present little detailed information is available about $C$. elegans $\mathrm{Y}$ family polymerases.

Here, we examined the sensitivity of $C$. elegans to UV radiation at various stages of embryogenesis using a feeding RNAi method. We show that suppression of $\mathrm{Ce}-\mathrm{POLH}$ in early embryogenesis and gametogenesis stages confers hypersensitivity to UV radiation but that suppression at later stages confers only modest sensitivity. Our data suggest a possible role for $\mathrm{Ce}$-Poln in damage tolerance during embryogenesis and gametogenesis.

\section{Materials and Methods}

\section{C. elegans culture}

Wild type N2 worms were grown on nematode growth medium (NGM) plates seeded with E. coli $\mathrm{OP} 50$ at $20^{\circ} \mathrm{C}$ (Sulston and Hodgkin, 1988).

\section{Cloning of the Ce-POLH and Ce-POLD genes}

To prepare the full-length coding region of F53A3.2, a DNA fragment containing the complete cDNA sequence was amplified by PCR from a C. elegans embryonic cDNA library, kindly provided by Dr. Hideyuki Okano (Department of Physiology; Keio University School of Medicine), using the following primers, $\mathrm{Ce}-\mathrm{POLH}$ 1: 5'-GGT TAC TAG TAT GAA AAG AGT GAT CAG CCT CAT-3' and Ce-POLH-2: 5'-GGT TCC CGG GTT AGG GTT TCT TCT TTT TGA AAA-3', containing nucleotides 2634926327 and 21212-21234 of the F53A3 cosmid clone (accession number: AF025460), respectively. PCR was performed as follows: initial denaturing at $94^{\circ} \mathrm{C}$ for $1 \mathrm{~min}$, followed by six cycles of $94^{\circ} \mathrm{C}$ for $30 \mathrm{~s}, 51^{\circ} \mathrm{C}$ for $30 \mathrm{~s}$, and $72^{\circ} \mathrm{C}$ for $1.5 \mathrm{~min}$, in which the annealing temperature was decreased $1{ }^{\circ} \mathrm{C}$ every two cycles until it reached $49^{\circ} \mathrm{C}$; followed by 24 cycles of $94^{\circ} \mathrm{C}$ for $30 \mathrm{~s}, 47^{\circ} \mathrm{C}$ for $30 \mathrm{~s}$, and $72^{\circ} \mathrm{C}$ for $1.5 \mathrm{~min}$; with a final elongation at $72^{\circ} \mathrm{C}$ for 10 min. PCR products were loaded onto a $1 \%$ agarose gel and purified using the QIAEX II gel extraction kit (QIAGEN) according to the manufacturer's instructions. Ce-POLD fragment was amplified by PCR using the following primers, $C e-P O L D-F$ : 5'-GGT AAC TAG TAT GAC CTC CAA GCG TCC TG-3' and Ce-POLD-R: 5'-CGA TCC CGG GTG GCA GTG ATA GAA CTT TAG CAC G-3', containing nucleotides 18897-18915 and 20269-20246 of the F10C2 cosmid clone (accession number: Z81497), respectively. PCR was performed as follows: initial denaturing at $94^{\circ} \mathrm{C}$ for $1 \mathrm{~min}$, followed by six cycles of $94^{\circ} \mathrm{C}$ for $30 \mathrm{~s}, 54^{\circ} \mathrm{C}$ for $30 \mathrm{~s}$, and $72^{\circ} \mathrm{C}$ for $1.5 \mathrm{~min}$, in which the annealing temperature was decreased $1{ }^{\circ} \mathrm{C}$ every two cycles until it reached $52^{\circ} \mathrm{C}$; followed by 24 cycles of $94^{\circ} \mathrm{C}$ for $30 \mathrm{~s}, 50^{\circ} \mathrm{C}$ for $30 \mathrm{~s}$, and $72^{\circ} \mathrm{C}$ for $1.5 \mathrm{~min}$; with a final elongation at $72^{\circ} \mathrm{C}$ for $10 \mathrm{~min}$. PCR products were digested with Spe I and Sma I and cloned into pBlueScript SK (Stratagen). The cloned products were sequenced on both strands with a BigDye terminator cycle sequencing kit (Applied Biosystems). Multiple sequence alignments were compiled using Clustal $\mathrm{W}<$ www.ebi.ac.uk/clustalw/ $>$.

\section{Amplification and analysis of predicted exon 7 of Ce-POLH}

Adult hermaphrodites were collected, suspended in $100 \mu$ disruption buffer (10 mM Tris-HCl, pH 7.5, 1 mM EDTA, pH 8.0 and $0.02 \%$ lysozyme), quickly frozen at $-80^{\circ} \mathrm{C}$ for $10 \mathrm{~min}$, and incubated at $37^{\circ} \mathrm{C}$ for $3 \mathrm{~h}$. Total RNA was extracted using the Total RNA Isolation kit (Macherey-Nagel, Inc.) according to the manufacturer's instructions, and then detected by RT-PCR using the following primers, $C e-P O L H-3$ : 5'-AAA GCG GCG ATT TAC GAT G-3', and Ce-POLH-4: 5'-TTT TGG TGT TGG ATT CGG C-3', corresponding to nucleotides 22460-22442 and 22311-22329 of the F53A3 cosmid clone, respectively. The same primers were used to amplify fragments from cDNA clone derived from $C$. elegans embryonic cDNA libraries. Amplified fragments were electrophoresed on a $15 \%$ acrylamide gel and visualized under UV light.

\section{Bacteria-mediated RNAi of Ce-POLH}

The vector L4440 (pPD129.36), which contains two convergent T7 RNA polymerase promoters in opposite orientation, and the

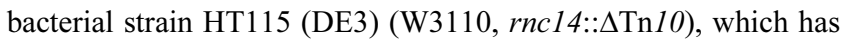
an IPTG-inducible T7 RNA polymerase gene and is deficient in RNase III, were kindly provided by Dr. A. Fire (Carnegie Inst., Washington). RNAi induced by the feeding method was performed as described (Kamath et al., 2000; Timmons et al., 2001). Briefly, the plasmids described above were digested with Spe I and Sma I. Similarly digested PCR products were inserted between the two T7 RNA polymerase promoters of L4440 (pPD129.36) and the resulting plasmids were transformed into HT115 (DE3) cells. IPTG $(1 \mathrm{mM})$ was added to transformed cells at log-phase and these were spread onto NGM agar plates containing $1 \mathrm{mM}$ IPTG and $50 \mu \mathrm{g} / \mathrm{ml}$ ampicillin, which were incubated for $24 \mathrm{~h}$ at $20^{\circ} \mathrm{C}$ and then used as RNAi plates. As a control, HT115 (DE3) cells transformed by the L4440 vector were plated. Worms at the young adult stage were placed on these plates and transferred to fresh RNAi plates after $12 \mathrm{~h}$ feeding. To investigate the effects of $\mathrm{Ce}$ - 
POLH RNAi after UV irradiation, F1 eggs laid over the next $5 \mathrm{~h}$ and young adult $\mathrm{F} 1$ worms were irradiated with a germicidal lamp $(254 \mathrm{~nm})$ at doses of $0,5,10,25,50 \mathrm{~J} / \mathrm{m}^{2}$. UV sensitivity was examined for the hatching abilities of the UV irradiated F1 eggs and F2 eggs laid by UV irradiated young adults. Hatching rates were scored $36 \mathrm{~h}$ after eggs were laid.

\section{RT-PCR analysis of Ce-POLH expression following $R N A i$}

The absence of $\mathrm{Ce}-\mathrm{POLH}$ transcripts following RNAi was examined by RT-PCR using the primers Ce-POLH-5: 5'-CGA ACT GCC GAG AAT CTG G-3' and Ce-POLH-6: 5'-GCG TGT CAA AAT TGT ACA GAA GTA AT-3', corresponding to nucleotides 23889-23871 and 21184-21209 of the F53A3 cosmid clone, respectively. As a control, $A C T-1$ transcripts were examined using the primers $C e-A C T-1-\mathrm{F}$ : 5'-CGT GGT TAC TCT TTC ACC ACC ACC GCT G-3' and $C e-A C T-1$-R: 5'-CAT TTA GAA GCA CTT GCG GTG AAC GAT GG-3', corresponding to nucleotides 29624-29651 and 30221-30193 of the T04C12 cosmid clone (accession number: Z81584), respectively. RT-PCR was performed as described (Hashmi et al., 2002). RNAi-treated adult hermaphrodites were collected, suspended in $100 \mu$ disruption buffer (10 mM Tris-HCl, pH 7.5, 1 mM EDTA, pH 8.0 and $0.02 \%$ lysozyme), quickly frozen at $-80^{\circ} \mathrm{C}$ for $10 \mathrm{~min}$, and then incubated at $37^{\circ} \mathrm{C}$ for $3 \mathrm{~h}$. RNA was extracted using the Total RNA Isolation kit (Macherey-Nagel, Inc.), and RT-PCR was carried out using the SuperScript One-Step RT-PCR System (Invitrogen) according to the manufacturer's instructions. Each $50-\mu 1$ reaction mixture was split into two tubes into which either $C e-P O L H$ or $C e-A C T-1$ specific primers were added. After 30-40 cycles of amplification, the RT-PCR products were separated on $1 \%$ agarose gels.

\section{Results}

\section{Sequence analysis of C. elegans POLH and Poly protein}

Information provided by the genomic sequencing consortium indicated that $C$. elegans has three Y-family DNA

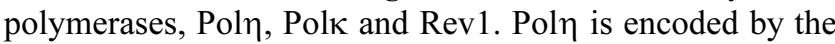
gene F53A3.2 and based on the genomic sequence was predicted to be composed of eight exons. This sequence was used to obtain $\mathrm{Ce}-\mathrm{POLH}$ cDNA by PCR of embryonic cDNA libraries with primers that included the predicted start $(C e-P O L H-1)$ and stop codons $(C e-P O L H-2)$. Sequencing of the cDNA clone thus obtained (accession number: $\mathrm{AB} 244413)$ revealed that it has a 57-bp deletion in predicted exon 7 with respect to the genomic sequence (Fig. 1B). To confirm whether Ce-POLH mRNA lacks these nucleotides, we performed RT-PCR with total RNA isolated from adult worms and primers flanking the deletion $(\mathrm{Ce}$ POLH-3 and Ce-POLH-4). As shown in Fig. 1C, RT-PCR (lane 1) gave rise only to a 93-bp PCR product which lacks the 57-bp sequence found in genomic DNA, as did PCR (lane 2) of the cDNA clone obtained from the C. elegans embryonic cDNA library. The corresponding amino acids encoded by the 57-bp sequence are also absent in cDNA sequences of human and Drosophila melanogaster Poln proteins. In fact, this region includes a splice site consensus sequence. Taking these results together, it is likely that the Ce-POLH gene consists of nine exons (Fig. 1A) and encodes a protein of 584 amino acids which shares $30 \%$ and 26\% identity with the human and Drosophila melanogaster Poln proteins, respectively (Fig. 1D).

\section{Effects of RNAi of Ce-POLH on C. elegans}

To investigate the role of Pol $\eta$ in C. elegans, Ce-POLH gene expression was suppressed by feeding worms with $E$. coli strains that contain plasmid vectors designed for the production of dsRNA by the bidirectional transcription of inserts (Timmons and Fire, 1998). Worms at the young adult stage were fed on E. coli producing dsRNA specific to $C e-P O L H$ or control E. coli transformed by the vector alone. F1 embryos from these RNAi-treated worms were also fed on RNAi plates. To confirm the absence of $\mathrm{Ce}$ POLH transcripts following RNAi treatment, RT-PCR using specific primers for Ce-POLH and for a control, $A C T-1$, which encodes the body wall actin gene, was carried out with total RNA prepared from RNAi-treated F1 adult worms. Fig. 2 shows that POLH mRNA is depleted in Polntargeted adults (lane 3) as compared with control worms (lane 1), while $A C T-1$ mRNA is expressed in both control and treated animals (lanes 2 and 4 ). F1 and F2 progeny from worms which were fed $E$. coli producing $C e-P O L H$-dsRNA hatched and grew normally, but eggs laid by worms which were fed $E$. coli producing $C e-P O L D$-dsRNA did not hatch (Table I). These results suggest that the replicative DNA polymerase, Pold, is essential for C. elegans embryogenesis, as expected, but that the TLS polymerase Pol $\eta$ is not.

\section{Effects of RNAi on C. elegans UV sensitivity}

The UV sensitivity of RNAi-treated worms was determined by monitoring the hatching rates of F2 embryos. The exper-

Table I. HATChING RATES OF UN-IRRADIATED EGgS

\begin{tabular}{lcccccc}
\hline \multirow{2}{*}{ RNAi } & \multicolumn{2}{c}{ F1 } & & \multicolumn{2}{c}{ F2 } \\
\cline { 2 - 3 } \cline { 5 - 6 } & eggs laid & hatched (\%) & & laid & hatched (\%) \\
\hline vector & 345 & 98.8 & & 1793 & 98.8 \\
RNAi-POLH & 378 & 96.0 & & 1639 & 96.5 \\
RNAi-POLD & 367 & 0 & & - & - \\
\hline
\end{tabular}

F1 eggs laid by worms that were fed $E$. coli producing $C e-P O L D$-dsRNA showed $100 \%$ embryonic lethality. F1 and F2 eggs from worms which were fed $E$. coli producing $C e-P O L H$-dsRNA developed normally as well as control eggs. 
(A)

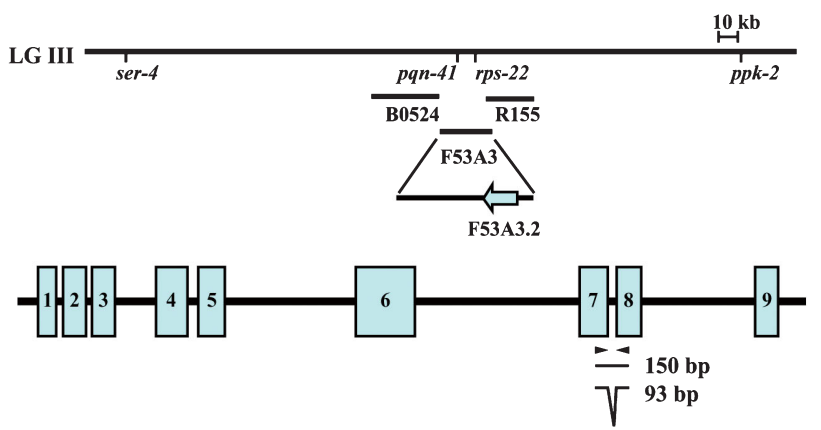

(C)

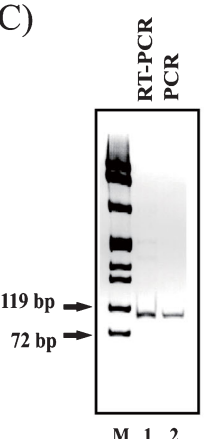

(B)

actccggtccetggacaccgccaattctcaacatttcactatcagcgacacgttttcaacccggaattcctgcacaaaatcgatcg attcacgaatggctttacgagaaaaaacgcgaaaatcgcgtcgaaaagcggcgatttacgatgaaaatgatggtcgagaagatgt gatttttgttgaaccgccggaaaaagtaccggaaaatgatcaaaatccgagtttttagtgaaaaatcgaatttttttcagctga aaagccgaatccaacaccaaaatccactggaacagacggagatttcattgttttaggctcagattcggatgatgacgttgtacag ccaaaactgatgataattggatttttgtcgatggaaagaattttcaaaaatggcctggaggcacctaccgcctgacattaaaag

(D)

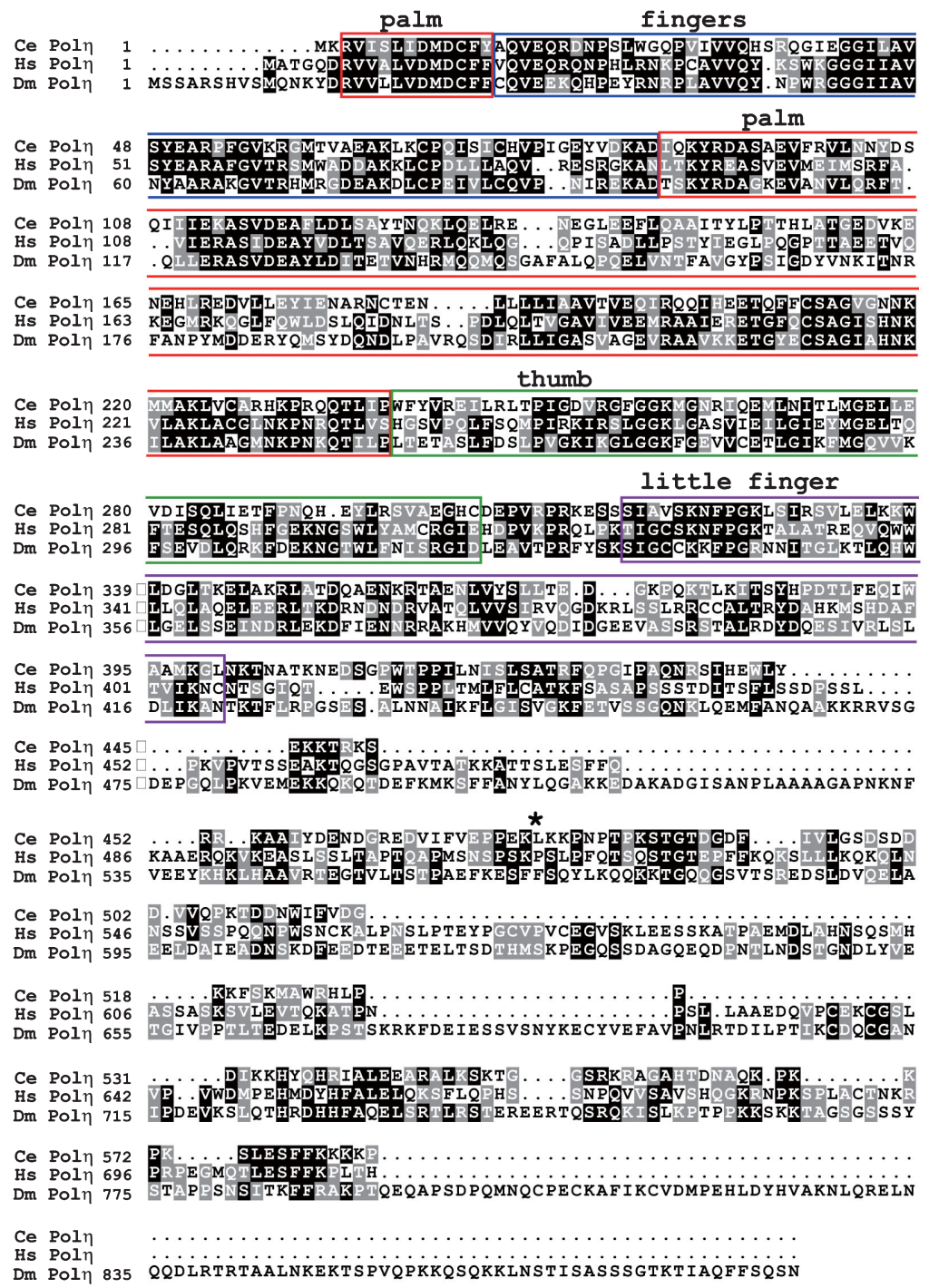

Fig. 1. 
imental scheme is shown in Fig. 3A. When previously laid

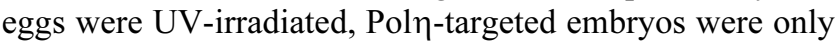
modestly sensitive compared with untargeted embryos (Fig. 3B). In contrast, Pol $\eta$-targeted F2 eggs laid 0-8 h after irradiation were clearly sensitive (Fig. 3C). In this case, eggs were irradiated while they were at the 32-blastomere stage and at the diakinesis-diplotene stages of oogenesis (Takanami et al., 2003). These results suggest that Pol $\eta$ significantly contributes to damage tolerance in C. elegans in early embryogenesis but less so in later stages. As early embryogenesis is characterized by high levels of replication, TLS by Pol $\eta$ may play an important role at this time. Interestingly, eggs laid 8-24 h after irradiation, which were exposed at the pachytene stage, also clearly showed UV sensitivity (Fig. 3D). To examine the contribution of Poln to damage tolerance in specific stages during embryogenesis in more detail, eggs at various developmental stages were irradiated and hatching rates were determined. The

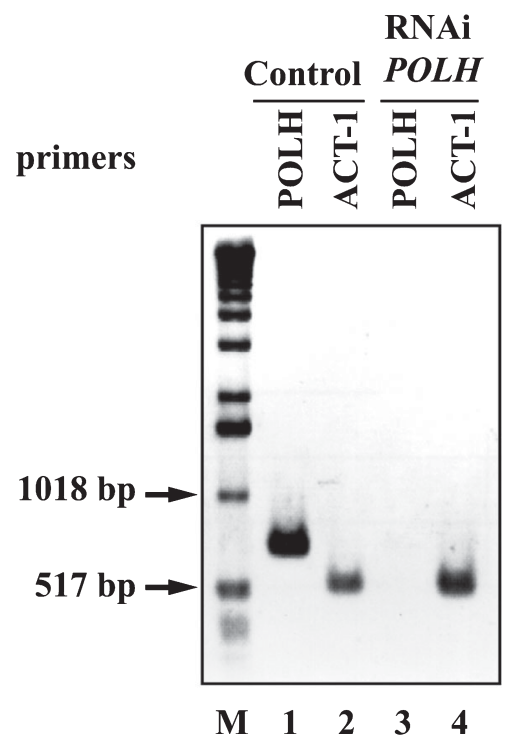

Fig. 2. RT-PCR of total RNA isolated from $F 1$ adult worms treated by RNAi ( $C e-P O L H$ or control vector). PCR primers were specific to the endogenous $\mathrm{Ce}-\mathrm{POLH}$ gene ( $\mathrm{Ce}-\mathrm{POLH}-5$ and $\mathrm{Ce}-\mathrm{POLH}-6)$ or to an internal control gene ( $C e-A C T-1-\mathrm{F}$ and $C e-A C T-1-\mathrm{R})$. Lanes 2 and 4, control $C e-A C T-1$ gene mRNA. Lanes 1 and $3, C e-P O L H$ mRNA. M, 1 kb DNA size marker. The figure is a negative image of an ethidium bromide-stained agarose gel. progression of gametogenesis and embryogenesis in $C$. elegans is conventionally classified into six periods (Fig. 4A) (Takanami et al., 2000). In control eggs, radiation sensitivity changed slowly throughout development, such that later-stage embryos were more sensitive than younger embryos (Fig. 4B). Periods II and III were the most UVsensitive stages of $\mathrm{Ce}$-POLH RNAi-treated eggs, but period I embryos were also somewhat sensitive (Fig. 4B and 4C). This result suggests that the genomic stability of fertilized eggs in early embryogenesis may depend on an accurate pathway using TLS to rapidly bypass DNA damage.

\section{Discussion}

In this paper, we examined the roles of the C. elegans XPV/ $P O L H$ homologue by the RNAi method. The embryos laid by worms treated by RNAi ( $\mathrm{Ce}-\mathrm{POLH})$ were not significantly different from those of control worms, and larvae did not show any defects and further development into adults was normal. This result suggests that $\mathrm{Ce}-\mathrm{Pol} \eta$ is not essential under normal growth conditions. On the other hand, we showed that the down-regulation of Poln in $C$. elegans results in an increased sensitivity to UV radiation by several development and differentiation processes, including meiosis and embryogenesis. It has been reported that wild-type C. elegans embryos are significantly more resistant to the effects of UV radiation on DNA synthesis than are those of other organisms (Hartman and Nelson, 1998). For example, the UV dose required to reduce DNA synthesis by $50 \%$ in wild type $C$. elegans is $200 \mathrm{~J} / \mathrm{m}^{2}$, a dose that in mammalian cells results in the rapid and permanent cessation of DNA synthesis (Hartman et al., 1991). NER is the main pathway involved in the removal of CPDs and (6-4) photoproducts induced by UV irradiation. However, in mammalian cultured cells, removal of (6-4) photoproducts is very fast, but CPD repair is much slower (Friedberg et al., 1995b). In contrast, the kinetics of repair of CPDs and (6-4) photoproducts in $C$. elegans from embryos to adults were similar to, if not slower than, that of CPDs in cultured human cells (Hartman et al., 1989). These data suggest that UV resistance in $C$. elegans embryos may depend on TLS, which rapidly bypasses DNA damage, in addition to the removal of damage by the NER system. Recently, it was reported that RNAi of the C. elegans homologues of human XPA (Park

Fig. 1. Gene and domain structure of Ce-POLH. (A) Genomic map of linkage group III (LG III) in relation to F53A3.2 and the intron/exon structure of the $\mathrm{Ce}-\mathrm{POLH}$ gene. The gene F53A3.2, which is located between the pqn-41 and rps-22 loci, consists of nine exons, instead of the eight exons previously assumed. Primer positions (arrow heads) used for RT-PCR and product sizes are indicated below the exon schematic. (B) Nucleotide sequence of exon 7 of the $\mathrm{Ce}-\mathrm{POLH}$ gene. The 57 bases surrounded by red box are deleted in the cDNA clone derived from the cDNA library. (C) RT-PCR with total RNA from adult worms and PCR of the cDNA clone derived from the cDNA library. M, $\phi X 174$ HaeIII DNA size marker. The figure is the negative image of an

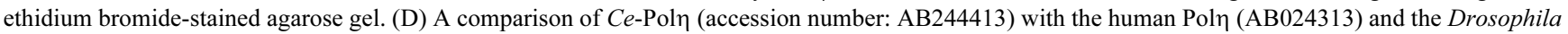
melanogaster Pol $\eta$ (AB049433) proteins. Identical and similar residues are shaded in dark and light gray, respectively. Palm (red), fingers (blue), thumb (green), and little finger (purple) domains are marked with boxes. The asterisk indicates the position of the 19 a.a. (57 bp) deletion. 


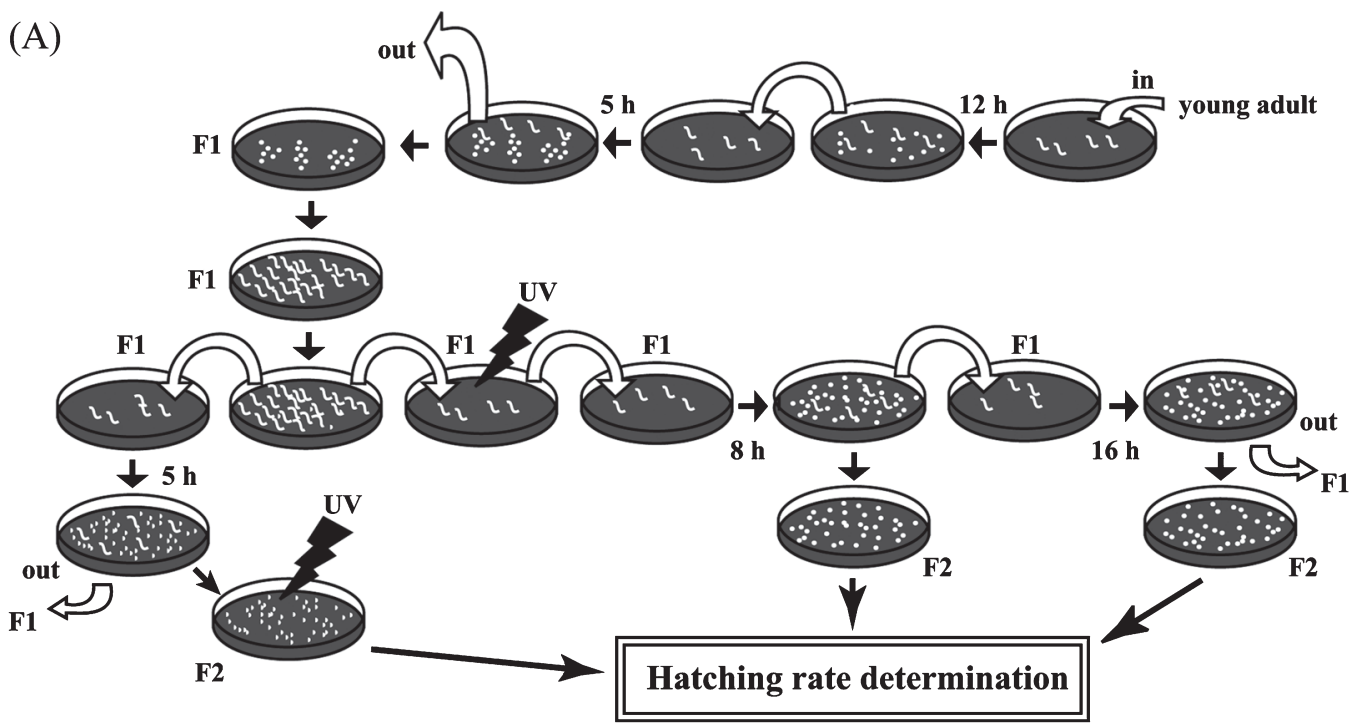

(B)

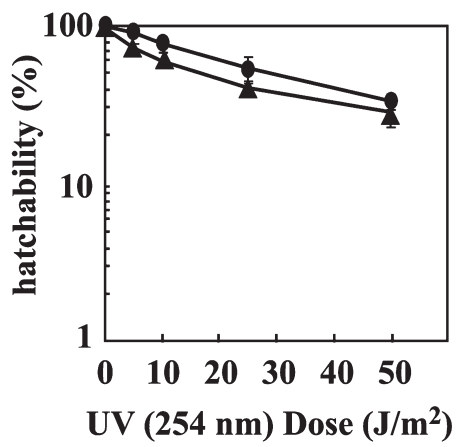

(C)

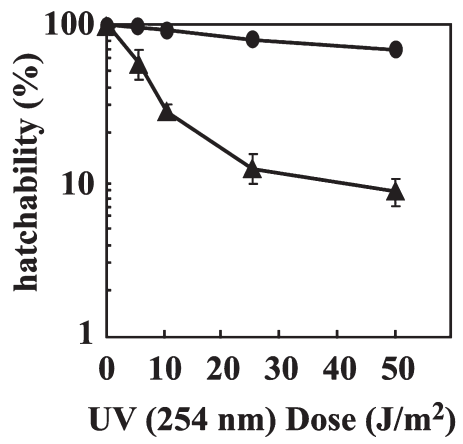

(D)

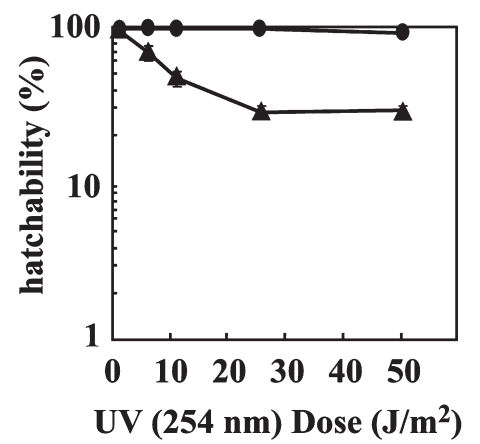

Fig. 3. Effects of Ce-POLH RNAi on the UV sensitivity of hatching. (A) Schematic of RNAi experiments. Young adults were placed on RNAi plates that contained bacteria producing $\mathrm{Ce}$-PolH-dsRNA. After $12 \mathrm{~h}$ feeding, the worms were transferred to fresh RNAi plates. F1 eggs laid over the next $5 \mathrm{~h}$ were used for experiments. Young F1 adults were transferred to fresh RNAi plates, and the hatching rates of F2 eggs irradiated with UV 0-5 h after laying, 0-8 h before laying, and 8-24 h before laying were determined. (B) F2 eggs laid over the course of 5 h by F1 worms were UV-irradiated and hatching rates were scored. (C) Young F1 adults were UV-irradiated, and the hatching rates of F2 eggs laid up to $8 \mathrm{~h}$ after irradiation were scored. (D) The hatching rates of F2 eggs laid during 8-24 h after irradiation were scored. Over 100 eggs were tested for each UV dosage in a single set of experiments, and each experiment was repeated three times. Error bars indicate standard deviations. Closed circles: control worms; closed triangles: $\mathrm{Ce}-\mathrm{POLH} \mathrm{RNAi}$-treated worms.

et al., 2002) and human XPF (Park et al., 2004), which participate in the NER pathway, increases the UV sensitivity of C. elegans embryos. It was also shown that down-regulation of $C S B$, which plays an important role in a NER subpathway, transcription-coupled excision repair, inhibits germ cell proliferation and enhances apoptosis after UV irradiation (Lee et al., 2002). However, embryos from worms in which $\mathrm{Ce}-\mathrm{POLH}$ expression is suppressed are much more sensitive to UV irradiation than are embryos in which XPA (Park et al., 2002), XPF (Park et al., 2004) or CSB (Lee et $a l ., 2002)$ is suppressed. For example, the hatching rate of eggs from $\mathrm{Ce}-\mathrm{POLH}$ RNAi worms irradiated with UV (50 $\mathrm{J} / \mathrm{m}^{2}$ ) was $61-64 \%$ lower than that of eggs from control worms (Fig. 3C and D), whereas the hatching efficiency of eggs from worms in which XPA (Park et al., 2002), XPF (Park et al., 2004) or CSB (Lee et al., 2002) was suppressed was only about $15 \%$ lower at the same UV dose. In rat male germ cells, intact early spermatocytes exhibit no or low NER activity, although cell extracts from early spermatocytes show high levels of incision activity. In contrast to somatic cells, little is known regarding the inhibition of the mutagenic effects of DNA damage in germ cells (Jansen et al., 2001). Rapidly proliferating germ cells and embryonic cells may be more dependent on Poln-mediated TLS than on NER in response to UV-induced DNA damage.

For various embryonic stages, we examined the effects of Ce-POLH RNAi on sensitivity to UV at a dose of $10 \mathrm{~J} / \mathrm{m}^{2}$ (Fig. 4B). The most UV-sensitive stages were periods II and 
(A)

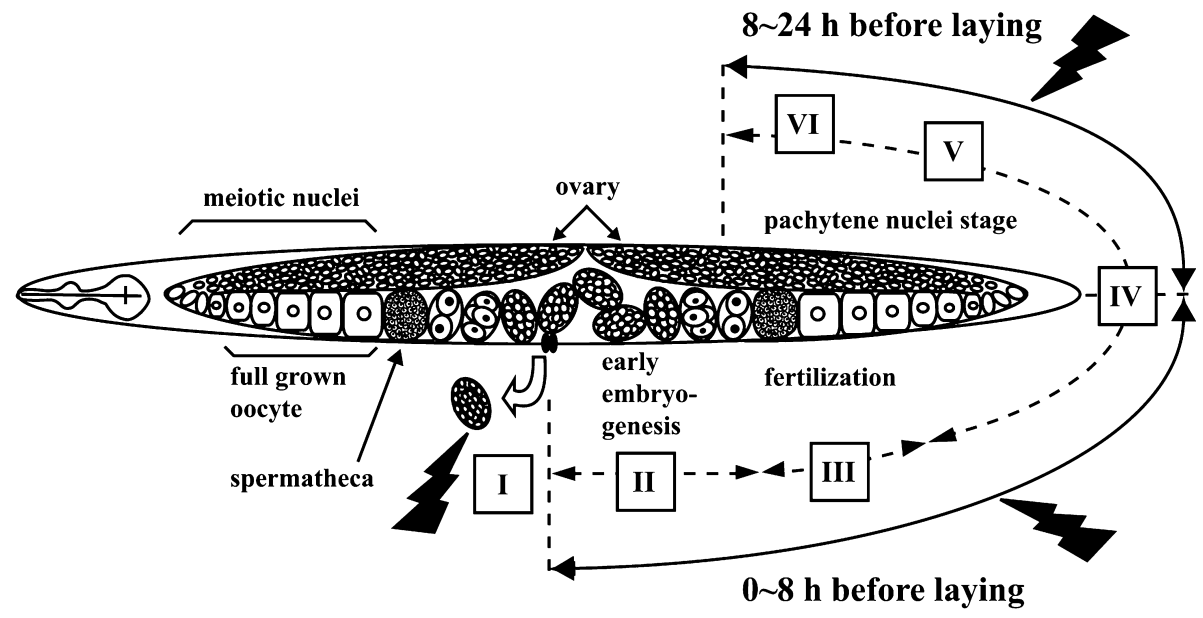

(B)

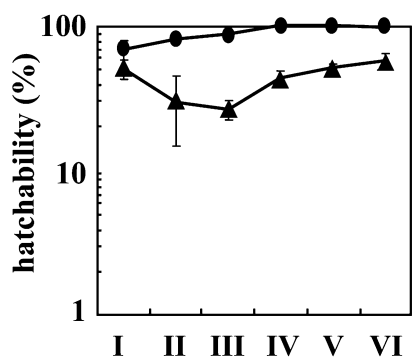

(C)

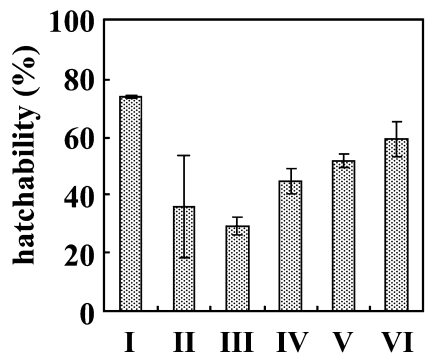

Fig. 4. UV sensitivities at various embryonic stages. (A) Schematic of gametogenesis and early embryogenesis in a young gravid hermaphrodite. Gametogenesis and embryogenesis are conventionally classified into six periods as described in (Takanami et al., 2000$)$. The eggs in period I (5 h after laying) contain $\sim 100-550$ nuclei and are at the stage from gastrulation to early morphogenesis. The eggs in period II ( $-0.5 \mathrm{~h}$ to $0 \mathrm{~h}$ after laying, with time 0 corresponding to the laying of the first egg) are at the early cleavage stage. The eggs in period III ( $-4 \mathrm{~h}$ to $-0.5 \mathrm{~h}$ after laying) are at the stage from full grown oocytes and to fertilization and early cleavage. The eggs in period IV ( $-8 \mathrm{~h}$ to $-4 \mathrm{~h}$ after laying) are at the oocyte to late pachytene stage. The eggs in period $\mathrm{V}(-16 \mathrm{~h}$ to $-8 \mathrm{~h}$ after laying) and VI ( $-24 \mathrm{~h}$ to $-16 \mathrm{~h}$ after laying) are at the pachytene nucleus stage. (B) UV sensitivity of eggs during periods I-VI. The survival of eggs laid during periods I-VI by a Ce-POLH RNAi hermaphrodite following UV irradiation of $10 \mathrm{~J} / \mathrm{m}^{2}$. Closed circles, eggs from control worms; closed triangles, eggs from $\mathrm{Ce}-\mathrm{POLH}$ RNAi worms. Independent triplicate experiments were carried out and the averages of scores from periods I-VI were 22, 3, 15, 18, 46 and 49 eggs per adult worm. Error bars indicate standard deviations. (C) Relative UV sensitivity of eggs during periods I-VI. The hatchability for eggs from Ce-POLH RNAi worms in Fig. 4B is expressed with respect to that for eggs from control worms in Fig. 4B as $100 \%$.

III, which include zygote formation, early cleavage, and establishment of embryonic axes, and the determination of somatic and germ-line founder cell fates after fertilization (Wood, 1988). In early C. elegans embryos, it was reported that the correct execution and timing of cell division is essential for proper cell fate patterning (Encalada et al., 2000). Conversely, embryos in period I, which covers the stage from gastrulation to early morphogenesis (Wood, 1988), were only moderately sensitive compared with controls (Fig. 3A, 4B and 4C), suggesting that Poln only modestly contributes to damage tolerance at this stage. Differences in these developmental stages may reflect distinct pathways that circumvent the effects of DNA damage. It was reported that $C e-r d h-51$, the RAD51 homologue of $C$. elegans, contributes to damage tolerance after X-ray irradia- tion most largely in meiotic pachytene nuclei (Takanami et al., 2000). Although stage-specific activities of NER have not been elucidated, it may be possible that alternative DNA repair pathways express in a stage specific manner.

In summary, our observations suggest that $\mathrm{Ce}$-Pol $\eta$ contributes to damage tolerance against UV irradiation to ensure the successful completion of embryogenesis, thus providings important insights into its role in DNA damage tolerance in germ and embryonic cells. C. elegans treated by RNAi is a good model system to investigate DNA repair in germ and embryonic cells. A drawback of this model system is that UV irradiation does not induce tumors in worms, regardless of the level of Ce-POLH expression. To further understand the role of Pol $\eta$, we are studying $X P V$-deficient mice in detail. 
Acknowledgements. We thank Dr. Hideyuki Okano for providing the $C$. elegans embryonic cDNA library and Dr. Andrew Fire (Carnegie Inst. Washington) for providing the bacterial strain HT115 (DE3) and the vector L4440 (pPD129.36). We are grateful to Dr. Yoshiaki Ohkuma, Dr. Masayuki Yokoi, and other members of Dr. Hanaoka's laboratory at Osaka University for helpful discussions. This work was supported by grants from the Ministry of Education, Culture, Sports, Science and Technology of Japan, by the Human Frontier Science Program, and by Solution Oriented Research for Science and Technology (SORST) from the Japan Science and Technology Agency.

\section{References}

Encalada, S.E., Martin, P.R., Phillips, J.B., Lyczak, R., Hamill, D.R., Swan, K.A., and Bowerman, B. 2000. DNA replication defects delay cell division and disrupt cell polarity in early Caenorhabditis elegans embryos. Dev. Biol., 228: 225-238.

Fischhaber, P.L. and Friedberg, E.C. 2005. How are specialized (lowfidelity) eukaryotic polymerases selected and switched with high-fidelity polymerases during translesion DNA synthesis? DNA Repair (Amst), 4: 279-283.

Frank, E.G., Tissier, A., McDonald, J.P., Rapic-Otrin, V., Zeng, X., Gearhart, P.J., and Woodgate, R. 2001. Altered nucleotide misinsertion fidelity associated with polt-dependent replication at the end of a DNA template. EMBO J., 20: 2914-2922.

Friedberg, E.C., Walker, G.C., and Siede, W. 1995a. DNA Repair and Mutagenesis. ASM Press, Washington, DC, pp.1-58.

Friedberg, E.C., Walker, G.C., and Siede, W. 1995b. DNA Repair and Mutagenesis. ASM Press, Washington, DC, pp.283-316.

Gerlach, V.L., Aravind, L., Gotway, G., Schultz, R.A., Koonin, E.V., and Friedberg, E.C. 1999. Human and mouse homologs of Escherichia coli DinB (DNA polymerase IV), members of the UmuC/DinB superfamily. Proc. Natl. Acad. Sci. USA, 96: 11922-11927.

Gibbs, P.E., McGregor, W.G., Maher, V.M., Nisson, P., and Lawrence, C.W. 1998. A human homolog of the Saccharomyces cerevisiae REV3 gene, which encodes the catalytic subunit of DNA polymerase $\zeta$. Proc. Natl. Acad. Sci. USA, 95: 6876-6880.

Gibbs, P.E., Wang, X.D., Li, Z., McManus, T.P., McGregor, W.G., Lawrence, C.W., and Maher, V.M. 2000. The function of the human homolog of Saccharomyces cerevisiae REV1 is required for mutagenesis induced by UV light. Proc. Natl. Acad. Sci. USA, 97: 4186-4191.

Hartman, P.S., Hevelone, J., Dwarakanath, V., and Mitchell, D.L. 1989. Excision repair of UV radiation-induced DNA damage in Caenorhabditis elegans. Genetics, 122: 379-385.

Hartman, P.S. and Nelson, G.A. 1998. Processing of DNA Damage in the Nematode Caenorhabditis elegans. In DNA Repair in Prokaryotes and Lower Eukaryotes (Nickoloff, J.A., Hoekstra, M.F., eds.). Humana Press, pp.557-576.

Hartman, P., Reddy, J., and Svendsen, B.A. 1991. Does trans-lesion synthesis explain the UV-radiation resistance of DNA synthesis in C. elegans embryos? Mutat. Res., 255: 163-173.

Hashmi, S., Britton, C., Liu, J., Guiliano, D.B., Oksov, Y., and Lustigman, S. 2002. Cathepsin L is essential for embryogenesis and development of Caenorhabditis elegans. J. Biol. Chem., 277: 3477-3486.

Jansen, J., Olsen, A.K., Wiger, R., Naegeli, H., de Boer, P., van der Hoeven, F., Holme, J.A., Brunborg, G., and Mullenders, L. 2001. Nucleotide excision repair in rat male germ cells: low level of repair in intact cells contrasts with high dual incision activity in vitro. Nucl. Acids Res., 29: 1791-1800.

Johnson, R.E., Kondratick, C.M., Prakash, S., and Prakash, L. 1999. hRad30 mutations in the variant form of xeroderma pigmentosum. Science, 285: 263-265.

Johnson, R.E., Washington, M.T., Prakash, S., and Prakash, L. 2000. Fidel- ity of human DNA polymerase $\eta$. J. Biol. Chem., 275: 7447-7450.

Kamath, R.S., Martinez-Campos, M., Zipperlen, P., Fraser, A.G., and Ahringer, J. 2000. Effectiveness of specific RNA-mediated interference through ingested double-stranded RNA in Caenorhabditis elegans. Genome Biol., 2: 1-10.

Kannouche, P. and Stary, A. 2003. Xeroderma pigmentosum variant and error-prone DNA polymerases. Biochimie, 85: 1123-1132.

Kusumoto, R., Masutani,C., Shimmyo, S., Iwai, S., and Hanaoka, F. 2004. DNA binding properties o human DNA polymerase $\eta$ : implications for fidelity and polymerase switching of translesion synthesis. Genes Cells, 9: $1139-1150$.

Lawrence, C.W. 2002. Cellular roles of DNA polymerase $\zeta$ and Rev1 protein. DNA Repair (Amst), 1: 425-435.

Lee, M.H., Ahn, B., Choi, I.S., and Koo, H.S. 2002. The gene expression and deficiency phenotypes of Cockayne syndrome B protein in Caenorhabditis elegans. FEBS Lett., 522: 47-51.

Lehmann, A.R., Kirk-Bell, S., Arlett, C.F., Paterson, M.C., Lohman, P.H., de Weerd-Kastelein, E.A., and Bootsma, D. 1975. Xeroderma pigmentosum cells with normal levels of excision repair have a defect in DNA synthesis after UV-irradiation. Proc. Natl. Acad. Sci. USA, 72: 219-223.

Lin, W., Xin, H., Zhang, Y., Wu, X., Yuan, F., and Wang, Z. 1999a. The human $R E V 1$ gene codes for a DNA template-dependent dCMP transferase. Nucl. Acids Res., 27: 4468-4475.

Lin, W., Wu, X., and Wang, Z. 1999b. A full-length cDNA of hREV3 is predicted to encode DNA polymerase $\zeta$ for damage-induced mutagenesis in humans. Mutat. Res., 433: 89-98.

Maher, V.M., Ouellette, L.M., Curren, R.D., and McCormick, J.J. 1976. Frequency of ultraviolet light-induced mutations is higher in xeroderma pigmentosum variant cells than in normal human cells. Nature, 261: 593-595.

Masutani, C., Kusumoto, R., Yamada, A., Dohmae, N., Yokoi, M., Yuasa, M., Araki, M., Iwai, S., Takio, K., and Hanaoka, F. 1999a. The XPV (xeroderma pigmentosum variant) gene encodes human DNA polymerase $\eta$. Nature, 399: 700-704.

Masutani, C., Araki, M., Yamada, A., Kusumoto, R., Nogimori, T., Maekawa, T., Iwai, S., and Hanaoka, F. 1999b. Xeroderma pigmentosum variant $(\mathrm{XP}-\mathrm{V})$ correcting protein from HeLa cells has a thymine dimer bypass DNA polymerase activity. EMBO J., 18: 3491-3501.

Masutani, C., Kusumoto, R., Iwai, S., and Hanaoka, F. 2000. Mechanisms of accurate translesion synthesis by human DNA polymerase $\eta$. EMBO J., 19: 3100-3109.

McCulloch, S.D., Kokoska, R.J., Masutani, C., Iwai, S., Hanaoka, F., and Kunkel, T.A. 2004. Preferential cis-syn thymine dimmer bypass by DNA polymerase $\eta$ occurs with biased fidelity. Nature, 428: 97-100.

McDonald, J.P., Tissier, A., Frank, E.G., Iwai, S., Hanaoka, F., and Woodgate R. 2001. DNA polymerase iota and related rad30-like enzymes. Phil. Trans. R. Soc. Lond. B., 356: 53-60.

Nelson, J.R., Lawrence, C.W., and Hinkle, D.C. 1996a. Deoxycytidyl transferase activity of yeast REV1 protein. Nature, 382: 729-731.

Nelson, J.R., Lawrence, C.W., and Hinkle, D.C. 1996b. Thymine-thymine dimer bypass by yeast DNA polymerase $\zeta$. Science, 272: 1646-1649.

Ogi, T., Kato, T. Jr., Kato, T., and Ohmori, H. 1999. Mutation enhancement by DINB1, a mammalian homologue of the Escherichia coli mutagenesis protein dinB. Genes Cells, 4: 607-618.

Ohashi, E., Bebenek, K., Matsuda, T., Feaver, W.J., Gerlach, V.L., Friedberg, E.C., Ohmori, H., and Kunkel, T.A. 2000a. Fidelity and processivity of DNA synthesis by DNA polymerase $\kappa$, the product of the human DINB1 gene. J. Biol. Chem., 275: 39678-39684.

Ohashi, E., Ogi, T., Kusumoto, R., Iwai, S., Masutani, C., Hanaoka, F., and Ohmori, H. 2000b. Error-prone bypass of certain DNA lesions by the human DNA polymerase к. Genes Dev., 14: 1589-1594.

Ohmori, H., Friedberg, E.C., Fuchs, R.P., Goodman, M.F., Hanaoka, F., Hinkle, D., Kunkel, T.A., Lawrence, C.W., Livneh, Z., Nohmi, T., 
Prakash, L., Prakash, S., Todo, T., Walker, G.C., Wang, Z., and Wodgate, R. 2001. The Y-family of DNA polymerases. Mol. Cell, 8: 7-8.

Park, H.K., Yook, J.S., Koo, H.S., Choi, I.S., and Ahn, B. 2002. The Caenorhabditis elegans XPA homolog of human XPA. Mol. Cells, 14: $50-55$.

Park, H.K., Suh, D., Hyun, M., Koo, H.S., and Ahn, B. 2004. A DNA repair gene of Caenorhabditis elegans: a homolog of human XPF. DNA Repair (Amst), 3: 1375-1383.

Stary, A., Kannouche, P., Lehmann, A.R., and Sarasin, A. 2003. Role of DNA polymerase $\eta$ in the UV mutation spectrum in human cells. J. Biol. Chem., 278: 18767-18775.

Sulston, J. and Hodgkin, J. 1988. Methods. In The Nematode Caenorhabditis elegans (Wood, W.B., ed.). Cold Spring Harbor Laboratory Press, Cold Spring Harbor, New York, pp.587-606.

Takanami, T., Mori, A., Takahashi, H., and Higashitani, A. 2000. Hyperresistance of meiotic cells to radiation due to a strong expression of a single recA-like gene in Caenorhabditis elegans. Nucl. Acids Res., 21: 4232-4236.

Takanami, T., Zhang, Y., Aoki, H., Abe, T., Yoshida, S., Takahashi, H., Horiuchi, S., and Higashitani, A. 2003. Efficient repair of DNA damage induced by heavy ion particles in meiotic prophase I nuclei of Caenorhabditis elegans. J. Radiat. Res. (Tokyo), 44: 271-276.

Timmons, L. and Fire, A. 1998. Specific interference by ingested dsRNA. Nature, 395: 854.

Timmons, L., Court, D.L., and Fire, A. 2001. Ingestion of bacterially expressed dsRNAs can produce specific and potent genetic interference in Caenorhabditis elegans. Gene, 263: 103-112.
Tissier, A., Frank, E.G., McDonald, J.P., Iwai, S., Hanaoka, F., and Woodgate R. 2000a. Misinsertion and bypass of thymine-thymine dimers by human DNA polymerase 1. EMBO J., 19: 5259-5266.

Tissier, A., McDonald, J.P., Frank, E.G., and Woodgate, R. 2000b. polt, a remarkably error-prone human DNA polymerase. Genes Dev., 14: 1642-1650.

Wang, Y.C., Maher, V.M., and McCormick, J.J. 1991. Xeroderma pigmentosum variant cells are less likely than normal cells to incorporate dAMP opposite photoproducts during replication of UV-irradiated plasmids. Proc. Natl. Acad. Sci. USA, 88: 7810-7814.

Wang, Y.C., Maher, V.M., Mitchell, D.L., and McCormick, J.J. 1993. Evidence from mutation spectra that the UV hypermutability of xeroderma pigmentosum variant cells reflects abnormal, error-prone replication on a template containing photoproducts. Mol. Cell. Biol., 13: 4276-4283.

Washington, M.T., Johnson, R.E., Prakash, and L., Prakash, S. 2001. Accuracy of lesion bypass by yeast and human DNA polymerase $\eta$. Proc. Natl. Acad. Sci. USA, 98: 8355-8360.

Waters, H.L., Seetharam, S., Seidman, M.M., and Kraemer, K.H. 1993. Ultraviolet hypermutability of a shuttle vector propagated in xeroderma pigmentosum variant cells. J. Invest. Dermatol., 101: 744-748.

Wood, W.B. 1988. Embryology. In The Nematode Caenorhabditis elegans (Wood, W.B., ed.). Cold Spring Harbor Laboratory Press, Cold Spring Harbor, New York, pp.215-229.

(Received for publication, November 24, 2005

and accepted, December 28, 2005) 